\author{
RENATA KAMIŃSKA \\ Uniwersytet Kardynała Stefana Wyszyńskiego w Warszawie \\ E-Mail: r_kaminska@uksw.edu.pl \\ ORCID ID: https://orcid.org/0000-0003-3357-1734
}

\title{
THE PRAETOR'S PROTECTION OF THE RURAL PRAEDIAL SERVITUDES
}

Servitutes praediorum rusticorum are the oldest of Roman land easements. Due to their enormous importance, they were included in the res mancipi, i.e. things especially important to the Romans. The purpose of rural land easements was to improve cultivation, in particular, facilitating access to lands as well as their irrigation ${ }^{1}$. This group of servitutes included, among others iter, that is, right of way, actus, which means cattle drive, and via, which included both of them. Each person authorized to perform land easements, both rural and urban, was provided with legal protection in the form of a civil law complaint. It was Ulpian who presented its essence in his commentary to the praetor's edict.

D. 8,5,2pr. (Ulp. 17 ad ed.): De servitutibus in rem actiones competunt nobis ad exemplum earum quae ad usum fructum pertinent, tam confessoria quam negatoria, confessoria ei qui servitutes sibi competere contendit, negatoria domino qui negat.

As stated in the fragment referred to above, there were easement complaints against the property (actiones in rem), like those concerning the usufruct, namely actio confessoria and actio negatoria. Actio confessoria was for those who claimed they should have received the easement, while

1 D. $8,4,1$ pr. 
action negatoria for those who denied that their property had to provide servitude.

Even more explicitly, the purpose of the actio confessoria was described by Ulpian in another passage of the same book of his commentary to the edict. D. 8,5,4,1 (Ulp. 17 ad ed.): "Qui iter sine actu vel actum sine itinere habet, actione de servitude utetur". As the jurist said, the man who had an iter without an actus or who had an actus without an iter could have brought an actio for a servitude. Thus, Ulpian stressed again the right of the person who had an easement of passage (ius eundi) $)^{2}$ or an easement of cattle drive to bring actio confessoria to protect the servitude. Actio confessoria was then a measure of procedural protection and, as such, served to establish, throughout the process, the existence or non-existence of a certain easement. Thus, the vindicatio servitutis presumed the acknowledgement of the servitude, which could not be exercised at all, or to a certain extent, due to fault of another person or persons. Because this actio was in rem, it was effective not only on the owner of the estate, but on every person who either obstructed, interfered or even questioned the plaintiff's right ${ }^{3}$. The focus of the claim is indicated by the intentio of actio confessoria, which read - si ius esse... ${ }^{4}$ The claimant bringing it demanded the ceasing of further disruptions and the establishment, acknowledgement and restitution of the existing easement ${ }^{5}$.

Ulpian explained this problem precisely in another passage of his statement retained in the Justinian Digests. D. 8,5,2,3 (Ulp. 17 ad ed.): "Pomponius dicit fructuarium interdicto de itinere uti posse, si hoc anno usus est: alibi enim de iure, id est in confessoria actione, alibi de facto, ut

2 D. 8,3,1pr. (Ulp. 2 Inst.): "Iter est ius eundi ambulandi homini, non etiam iumentum agenda". Cf. V. Arangio-Ruiz, Per la classificazione delle servitù di passaggio, in: Studi in onore di Biagio Brugi, (1910), pp. 11, 16. Reprint in: Studi di diritto romano, 1 (1974), pp. 309, 314.

3 B. Biondi, Le servitù prediali nel dirito romano, (1954), pp. 343, 353; V. Arangio-Ruiz, La struttura dei diritti sulla cosa altrui in diritto romano, (1951), p. 163.

4 A. Rodger, Owners and Neighbours in Roman Law, (1972), pp. 31, 117; D. Mantovani, Le formule del processo privato romano. Per la didattica delle Istituzioni di diritto romano, (1999), pp. 35-37; S. Seyed-Mahdavi Ruiz, Die rechtlichen Regelungen der Immissionen im römischen Recht und in ausgewählten europäischen Rechtsordnungen, (2000), p. 117.

5 O. Pistolesi, Le attività di ripristino nelle servitù di iter, actus e via, in: Studi in onore di Arnaldo Biscardi, ed. by F. Pastori, 5 (1984), p. 281; F. Zuccotti, Le servitù prediali nel mondo antico; dogmatica romanistica e prospettive storico-comparatistiche, in: Studi in onore di Remo Martini, 3 (2009), p. 991. 
in hoc interdicto, quaeriturm". The jurist quoted Pomponius' opinion, who said that an usufructuary could proceed by way of interdictum de itinere if he had had used iter within the year, for there are two types of inquiry: one dealing with questions of law, as is the case in the actio confessoria; and the other with questions of fact, as in the aforesaid interdict. The basic difference between interdicts and the actio confessoria was that the complaint was a procedural measure, while the latter an extrajudicial one. That, in turn, means that the action was to investigate legal issues concerning easement ("alibi enim de iure, id est in confessoria actione"), while the aim of the interdictum was to determine the conditions of, and to protect the performance of the easement ${ }^{6}$.

Following on from Ulpian's argument, there were two means of legal protection of servitutes: one was the actio confessoria, with the premise to examine and protect the legal position, while the second was the interdicts, by means of which it was intended to establish the facts. This was the opinion of an Italian researcher, Siro Solazzi ${ }^{7}$, who listed the following interdicts from this group: interdictum de itinere actuque private (D. 43,19$)^{8}$,

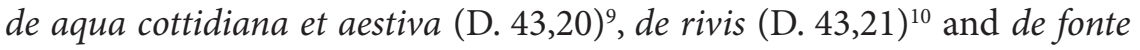
(D. 43,22$)^{11}$. His opinion raises the question as to what criteria the Romans used when they provided interdictal protection only for these easements. It is difficult to answer this question unambiguously. It can be guessed that such regulation was influenced by the purpose of the servitutes praediorum rusticorum.

A direct and seemingly one of the most important consequences of extending the praetor's protection over these easements was giving the possessors the possibility to use them, not only the owners of the dominant estate, as it is the case with actio confessoria. This is a very important issue, considering that the easement was maintained as a consequence of its exercise, regardless of whether it was exercised by the entitled person himself, that is the owner, or the possessor of the property (even if he was

6 G. Grosso, Le servitù prediali nel diritto romano, (1969), p. 179.

7 S. Solazzi, La tutela e il possesso delle servitù prediali, (1949), p. 51.

8 O. Lenel, Das Edictum perpetuum, (1927), pp. 478-479.

9 Ibidem, p. 479.

10 Ibidem, p. 480.

11 Ibidem; F. Bernard, The First Year of Roman Law, (2009), p. 249. 
in bad faith $\left.{ }^{12}\right)$. It was Scaevola who explained this point more precisely. D. 8,6,20 (Scaev. 1 reg.): "Usu retinetur servitus, cum ipse cui debetur utitur quive in possessionem eius est aut mercennarius aut hospes aut medicus quive ad visitandum dominum venit vel colonus aut fructuarius". He stated that a servitude was retained by use when it was exercised by the person who was entitled to it or who was in possession of it, or by his hired servant, guest, doctor or someone who had come to visit the owner or his agricultural tenant or an usufructuary, even although the usufructuary should have exercised it in his own name ${ }^{13}$.

The necessary requirement was that the person exercising the easement should be convinced that they were implementing the right to which they were entitled as another jurist, Paulus emphasized. D. 8,6,25 (Paul. 5 sent.): "Servitute usus non videtur nisi is, qui suo iure uti se credidit: ideoque si quis pro via publica vel pro alterius servitute usus sit, nec interdictum nec actio utiliter competit". He put that a man was not considered to be making use of a servitude unless he believed that he was exercising a right which belonged to him. Consequently, if a man made use of a servitude as if he had been using a public roadway or a servitude belonging to someone else, he was not entitled to any interdict or action. Thus the above-mentioned fragments of sources show that as long as solely the owner of the dominant estate was entitled to a complaint, anybody, including the owner, could request an interdict. Such regulation was assuredly connected with the purpose the actio confessoria or the interdictum was to serve. In the case of the complaint, its purpose was to determine the existence of the right and to protect it. In the case of the interdict, it was only of the state of affairs. For this reason, introducing the possibility to use an interdict was advantageous for entities exercising easements. In many cases, the intention of the entitled was not so much to determine the existence of their right, but to determine whether their activities were within the scope of the easement. The introduction of protection through undoubtedly widened the spectrum of entities which could seek protection. The entitled could indeed personally

12 D. 8,6,22 (Scaev. 1 reg.): Denique quicumque quasi debita via usus fuerit, D. 8,6,23 (Paul. 5 sent.): (sive ad fundum nostrum facit, vel ex fundo); D. 8,6,24 (Scaev. 1 reg.): Licet malae fidei possessor sit, retinebitur servitus.

13 D. 8,6,21 (Paul. 5 sent.): [...] fructuarius licet suo nomine. 
exercise the easement or through another person who was a proprietor, e.g. a worker.

Apart from the fact of exercising the easement, which could be called an objective element of the interdictal protection, there was also a subjective element, identified by Paulus in the above cited passage of his statement (D. 8,6,25). Its essence was the awareness of the possibility to use iter by the person. Only those who were convinced that they were entitled to exercise the easement could use interdictum or actio utilis ${ }^{14}$.

Interdictum de itinere actuque privato conforms to these general rules of the extrajudicial protection of rural easements. It is demonstrated in its formula, preserved thanks to Ulpian. D. 43,19,1pr. (Ulp. 70 ad ed.): Praetor ait: "Quo itinere actuque privato, quo de agitur, vel via hoc anno nec vi nec clam nec precario ab illo usus es, quo minus ita utaris, vim fieri veto". The praetor issued a general ban on preventing anyone to use iter, actus or via that were done the previous year, unless that use was gained with the use of force, secretly or precariously. Fundamentally, what made it possible to use interdictum de itinere actuque privato was determined by the correctness of having any of the easements mentioned by the praetor. Nevertheless, its formula raises some doubts. The first one concerns the expression - itinere actuque privato and the legitimacy to deem both servitudes private. The premise of servitutes praediorum rusticorum, was to burden other's private property with a third party's right. Hence, the argument advanced in the doctrine that the term privato is a gloss, seems correct. The doubt about whether the interdict concerned public roads can be explained only this way. Another doubt is raised by the term via appearing in the de itinere actuque privato formula ${ }^{15}$. The praetor issuing this interdict announced that he would grant it for those entitled to iter and actus (Quo itinere actuque privato). Afterwards, he added the term via. Controversy arises mainly because via encompassed ius eundi and ius agendi, so it included iter and $\operatorname{actus}^{16}$. The exact description was given by Ulpian. D. 8,3,1pr. (Ulp. 2 Inst.): "Via est ius eundi et agendi et ambulandi: nam et iter et actum in se via

14 L. Capogrossi Colognesi, La struttura della proprieta e la formazione dei iura praediorum nelleta repubblicana, (1976), p. 411.

15 R. Kamińska, Procesual and Extrajudicial Protection of Easment of Passage in Roman Law, in: Alternative Dispute Resolution: From Roman Law to Contemporary Regulations, ed. by B. Sitek et al., (2016), p. 171.

16 Lenel, Das Edictum, p. 478, footnote 10; Solazzi, La tutela, p. 52. 
continent". As stated by the jurist, via was the right to go on foot, to drive, and to walk; in fact, via embraces both iter and actus.

Therefore a question arises, whether interdictum de itinere actuque privato did also protect this easement? There has been a dispute about it in the doctrine. Vincenzo Arangio-Ruiz ${ }^{17}$ has no doubts that the interdict in question was applicable also with via. Siro Solazzi ${ }^{18}$, by contrast, thinks that although in the sense of the praetor's edict, iter actuque were nothing but the via, it does not change the fact that the interdict related solely to these two servitudes: iter and actus. The following fragment of Ulpian's commentary to the edict is crucial to understand the issue of the time and scope of application of de itinere actuque private.

D. 43,19,1,2 (Ulp. 70 ad ed.): Hoc interdicto praetor non inquirit, utrum habuit iure servitutem impositam an non, sed hoc tantum, an itinere actuque hoc anno usus sit non vi non clam non precario, et tuetur eum, licet eo tempore, quo interdictum redditur, usus non sit. Sive igitur habuit ius viae $^{19}$ sive non habuit, in ea condicione est, ut ad tuitionem praetoris pertineat, si modo anno usus est vel modico tempore, id est non minus quam triginta diebus. Neque ad praesens tempus refertur usus, quia plerumque itineribus vel via non semper utimur, nisi cum usus exegerit ita.

In the very first words, the jurist emphasized that by granting the interdict de itinere actuque privato, the praetor did not verify whether the person requesting it had a valid easement, but only if he used the right of passage and cattle drive within a year in the correct way, that is, without using force, secretly or precariously. If such circumstances did not occur, the official protected the person requesting the interdict regardless of whether he performed iter in the same time when he asked for the interdict. Thus, as Ulpian summarized, regardless of whether a person had a valid easement or not, the person could ask the praetor for protection. The only requirement was that the easement had to be performed for a year or shorter, but not shorter than 30 days. The use did not refer to actual present time, as usually iter or via were not used constantly, but as necessary.

\footnotetext{
17 Lenel, Das Edictum, p. 478, footnote 11, who states that this term is a gloss.

18 Arangio-Ruiz, Per la classificazione, p. 303.

19 Solazzi, La tutela, p. 52.
} 
The above fragment contains the second statement of Ulpian (after the one preserved in D. 8,5,2,3), in which he stated that the premise of an interdict was only to probe the state of affairs and that was the basis for awarding the legal protection that it provided. In other words, the person requesting the interdictal protection was entitled to it, irrespective of the existence of an easement established on the strength of the law. One can have an impression that with the words - "Sive igitur habuit ius viae sive non habuit, in ea condicione est, ut ad tuitionem praetoris pertineat" the jurist emphasized the independence in using interdicts from the existence of an easement ${ }^{20}$. Ulpian's further words seem to have a similar tone. D. 43,19,1,4 (Ulp. 70 ad ed.): "Si quis hoc interdicto utatur, sufficit alterutrum probare vel iter vel actum in usu habuisse". He put that the person who wanted to use interdictum de itinere actuque privato was only required to prove that they used the right of passage or cattle drive. For that reason, anyone who correctly used the ius eundi could request and receive the interdict, whether they were the owner of the dominant estate or not ${ }^{21}$.

It seems highly probable that the very fact of correctly acquiring and performing the activities corresponding with iter or actus was sufficient, and it constituted one of the necessary premises to receive interdictum de itinere actuque privato ${ }^{22}$. These are the jurist's words that incline to such a conclusion. D. 43,19,1,3 (Ulp. 70 ad ed.): "Annui temporis spatio conclusit usum. Annum ex die interdicti retrorsum computare debemus". Ulpian explained that its use was concluded by the space of a year's time, and it must have been counted a year back from the day of the issuance of the interdict.

The second premise was the time to use the servitude, usually a year or shorter, but no less than 30 days. It has to be remembered, that not exercising the ius eundi for a year effected in irreversibly, forfeiting the opportunity to use the interdict. On the other hand, bearing in mind that in case of easement the purpose of the interdictal protection was only to protect that state of affairs, it can be presumed that great attention was paid

20 Most probably ius viae is a gloss. Cf. Solazzi, La tutela, p. 52.

21 S. Solazzi, Requisiti e modi di costituzione delle servitù prediali, (1938), p. 139.

22 Capogrossi Colognesi, La struttura, p. 408; F. Zuccotti, Sulla tutela processuale processuale delle servitù cosiddette pretorie, in: Atti del Convegno Processo civile e processo penale nellesperienza giuridica del mondo antico, (Collana della Rivista di diritto romano 2011), p. 368. 
to whether the person asking for the interdict was really using the right of passage. D. 43,19,3,3 (Ulp. 70 ad ed.): "In hoc interdicto examinatur, quanti eius interesset via non prohiberi sive itinere". Ulpian expressed an opinion that in the interdictum de itinere actuque privato, the benefits gained by the person were taken into account, for example because of the fact that he had not been forbidden to use the right of passage and cattle drive. The jurist suggested explicitly that one of the more important circumstances analyzed in the proceedings based on this interdict was the fact that the entitled person benefitted from performing iter or actus. Separating the interdictal protection of servitudes from their legal basis shows that the purpose of the interdicts in this case was securing real dependences interconnecting farming lands, which certainly contributed to increasing the conditions of farming and cultivation ${ }^{23}$.

Owing to the fragments of the jurists' writings preserved in the Digests, one may cognize definite examples of application of interdictum de itinere actuque privato. One of them was described by Ulpian. D. 8,3,3,3 (Ulp. 17 ad ed.): "Qui habet haustum, iter quoque habere videtur ad hauriendum et, ut ait Neratius libro tertio membranarum, sive ei ius hauriendi et adeundi cessum sit, utrumque habebit, sive tantum hauriendi, inesse et aditum sive tantum adeundi ad fontem, inesse et haustum. Haec de haustu ex fonte private". The jurist focused his attention on two servitudes - aquae haustus and iter. He wanted to determine the relation between them. Since if the spring being the subject of the aquae haustus servitude was inside the servient estate, it was obvious that the entitled had to cross that land, or at least a part of it, on a regular basis. Was this reason enough to deem him entitled to perform the ius adeundi? Ulpian illustrated the problem proving three possible states of affairs and appropriate legal solutions. In the first one, if the right to draw water and to access the intake had been granted to a person, then they could use both rights. In the second situation, if the person had received only the right to draw water, it presumed that the right to access the intake was within it. If the person had only received the right to access the spring, it was similarly understood that it also contained the right to draw water.

23 Zuccotti, Le servitù, p. 984. 
A similar case was described by the same jurist in another fragment of his commentary to the praetor's edict, except that the servitude was personal.

D. 8,5,2,2 (Ulp. 17 ad ed.): Recte Neratius scribit, si medii loci usus fructus legetur, iter quoque sequi (per ea scilicet loca fundi, per quae qui usum fructum cessit constitueret) quatenus est ad fruendum necessarium: namque sciendum est iter, quod fruendi gratia fructuario praestatur, non esse servitutem, neque enim potest soli fructuario servitus deberi: sed si fundo debeatur, et ipse fructuarius ea utetur.

Ulpian referred to the situation when the ususfructus was established in the middle of someone's land. It was complicated because exercising this servitude implied the necessity of the entitled to regularly access that part of the plot. There was a question about whether the user could also use the right of passage through this plot. Ulpian stated, quoting Neratius, that in such a case, the usufructuary was also entitled to iter, however only through the part of the parcel where the passage was demarcated by the person granting the usufruct, and only in the range necessary to exercise the easement. It has to be remembered, as stressed by the jurist, that the right of passage awarded to the user in order to enable him to exercise another given right was not a servitude on its own. The user of the ususfructus of the land was not entitled to any easements. But if there was the right of passage connected with this land, the user could have exercised it as well.

In both quoted fragments (D. 8,3,3,3 and D. 8,5,2,2) iter was shown as an element necessary to exercise another servitude. For that reason, as the jurist explained, even if in any of the described situations, the owner of the servient estate did not establish ius eundi, it was thought obvious that the entitled also used $\mathrm{it}^{24}$. This dependence of the servitudes must have influenced their existence and expiration. D. 8,6,17 (Pomp. 11 variis lectionibus): "Labeo ait, si is, qui haustum habet, per tempus, quo servitus amittitur, ierit ad fontem nec aquam hauserit, iter quoque eum amisisse". Labeo, followed by Pomponius, expressed an opinion that not exercising the right to draw water caused a cease of the right of passage. This solution seems justified; if iter ad hauriendum was only a means to an end, it had to expire with the

\footnotetext{
24 Solazzi, La tutela, p. 51.
} 
main servitude that it facilitated ${ }^{25}$. Hence, as Pomponius explained, even if the entitled walked to the spring but did not draw water, the servitude and iter expired.

The above cited fragments of the jurists' comments quoted above provide a picture of the right of passage as a 'supplementary law' of a kind, necessary to exercise the 'primary' servitude, without regard to the servitude being an easement or a personal servitude. As long as in case of aquae haustus, a statement that it also contained iter does not raise major doubts, because in both cases, the servitudes concerned land, but in regard to ususfructus it is an issue raising concern. The ususfructus was a personal servitude and that is why, as Ulpian explained (D. 8,5,2,2), iter could not be treated as a servitude, because being a land servitude, a user would not have been entitled to it. It is different if the land had already had such a servitude. There was no hindrance for the usufructuary to use it. This situation must have been beneficial not only for the entitled person, who did not feel anxious about where to cross, but also for the owner of the estate providing both servitudes. When the route of passage was demarcated, his property was not exposed to any interference. Besides, the iter itself constituted a restriction in ownership ${ }^{26}$. Using the existing right of passage did not make the user acquire that right. Performing activities arising from iter was still a matter of fact, not a matter of law. In other words, the usufructuary only had a right of passage through the land, but they did not possess any land servitudes. This issue, basing upon the cited source, can be viewed from another perspective. The right of way was exercised not only by those for whom the right had been awarded or who inherited it. It was also exercised by those who crossed someone else's land, so they behaved as if they were entitled because of iter, but knowing that they were not entitled to it ${ }^{27}$. They did not usurp any rights, only used a certain state of affairs. The situation described by Neratius and Ulpian (D. 8,3,3,3 and D. 8,5,2,2) was then uncomfortable for the usufructuary, insofar as if there were any trespasses to their ius eundi they could not bring the actio confessoria. The latter, as it had been stated,

25 M. Fiorentini, Struttura ed esercizio della servitù d'acqua nell'esperienza giuridica romana, in: Quaderni del Dipartimento di Scienze Giuridiche, 8 (2003), p. 89.

26 Ibidem, p. 182; Kamińska, Procesual and Extrajudicial, p. 179.

27 R. Caravella, Le limitazioni del dominio per ragioni di vicinanza in diritto romano, (1971), p. 58. 
aimed at ascertaining whether the right existed. If, in the discussed case, the target was to determine the state of affairs, then the available means was only an interdict ${ }^{28}$. The only requirement they had to fulfil was practically exercising the right of passage for a given time, which was pointed out by Pomponius as well as by Ulpian (D. 8,5,2,3), who said that the user who had performed iter within the previous year, could obtain interdictum to protect it. Thus, irrespectively of the existence of the servitude and the claim devised to protect it, the praetor announced the issuance of interdicts. They were created to determine the actual state and to protect the person who was in it, not entitled in the easement but performing activities corresponding with the easement ${ }^{29}$.

The praetor's protection of servitutes praediorum rusticorum was therefore implemented by interdicts, which provided effective protection in non-litigious proceeding. Thus they were an excellent alternative to the actio confessoria, and often even the only way of protection, since in their case, it were only the actual facts that had meaning, not the law. This type of protection proved to be particularly useful in the case of such servitutes as iter, which often did not occur alone, but were treated as a means of enabling other easements. The advantage of interdicts was that they allowed the entitled person to protect the mere fact of performing a given easement without having to initiate a trial.

Whereas the actio confessoria was a claim effective erga omnes available to the person entitled to easement when the servient estate owner, or any other person, impeded its exercise or questioned its authorization. Its purpose, unlike interdicts, was to establish the existence of the infringed right of the plaintiff and eliminate any obstacles precluding the full exercise of the servitude. Therefore, the praetor's interdicts perfectly complemented the protection of the easement provided by ius civile ${ }^{30}$. For, depending on the circumstances and the purpose that the entitled person intended to reach, he could have lodged a complaint or ask the praetor for an interdict. It is possible that such a solution was primarily influenced by the specificity of the legal and neighborly relationship in villages, as well as the very essence

\footnotetext{
28 D. 8,6,5; 6; Solazzi, La tutela, p. 58.

29 Zuccotti, Sulla tutela, pp. 364-365, footnote 123.

30 Biondi, Le servitù, p. 355; Arangio-Ruiz, La struttura, p. 210.
} 
of rural easements, since they, namely iter, actus and via, had guaranteed double protection by both the civil law and the praetor ${ }^{31}$.

Translated by

Teresa Bałuk-Ulewiczowa

\title{
PRETORSKA OCHRONA SŁUŻEBNOŚCI GRUNTOWYCH WIEJSKICH
}

\section{STRESZCZENIE}

Ius civile zaliczało servitutes praediorum rusticorum do res mancipi, a więc wyjątkowo ważnych dla Rzymian. Zapewniało im również ochronę skutecznej erga omnes, realizowaną na drodze actio confessoria. Obok niej istniała pozaprocesowa ochrona służebności. Roztaczał ją pretor, który udzielał interdyktów. Wśród nich znajdował się interdictum de itinere actuque private służący do ustalenia i ochrony stanu faktycznego istniejącej służebności przechodu (iter).

\section{PRÄTORIANISCHER SCHUTZ DER LÄNDLICHEN GRUNDDIENSTBARKEIT}

\section{ZUSAMMENFASSUNG}

Ius civile umfasste die großen Themen von servitutes praediorum rusticorum bis res mancipi, also für die Römer äußerst wichtige Gesetzgebungsbereiche. Es versicherte ihnen auch den Schutz der effektiven erga omnes, die durch actio confessoria durchgeführt wurde. Daneben gab es einen außergerichtlichen Schutz der Dienstbarkeit. Dieser wurde vom Prätor gewährleistet, der Interdikte auferlegen konnte. Unter ihnen befand sich das interdictum de itinere actuque private, mit dem die Feststellung und der Schutz des tatsächlichen Sachverhaltes des bestehenden Wegerechtes (iter) geregelt wurde.

\author{
Übersetzt von \\ Renata Skowrońska
}

\section{The Praetor's Protection of the Rural Praedial Servitudes}

\section{SUMMARY}

Ius civile included servitutes praediorum rusticorum to the res mancipi, which were the things mostly important for the Romans. The law also provided them with protection realized through the actio confessoria effective erga omnes. Apart from that, there was also an out-of-court easement protection. It was provided by the praetor who used interdicts. Among them was interdictum de itinere actuque private to determine and protect the actual state of the existing easement of passage (iter).

31 Pistolesi, Le attività, p. 270. 


\section{SŁOWA KLUCZOWE / SCHLAGWORTE / KEYWORDS}

- servitudes, interdicts, interdictum de itinere actuque privato, actio confessoria

\section{BIBLIOGRAFIA / BIBLIOGRAFIE / BIBLIOGRAPHY}

\section{ŹRÓDŁA / QUELLEN / SOURCES}

D. $8,3,1 \mathrm{pr}$.

D. $8,3,3,3$

D. $8,4,1$ pr.

D. $8,5,2$ pr.

D. $8,5,2,2$

D. $8,5,2,3$

D. $8,5,4,1$

D. $8,6,5$

D. $8,6,6$

D. $8,6,17$

D. $8,6,20$

D. $8,6,21-23$

D. $8,6,25$

D. $43,19,1$ pr.

D. $43,19,1,2$

D. $43,19,1,3$

D. $43,19,1,4$

D. $43,19,3,3$

\section{LITERATURA / LITERATUR / LITERATURE}

Arangio-Ruiz V., La struttura dei diritti sulla cosa altrui in diritto romano, (1951).

Arangio-Ruiz V., Per la classificazione delle servitù di passaggio, in: Studi in onore di Biagio Brugi (1910). Reprint in: Studi di diritto romano, 1 (1974).

Bernard F., The First Year of Roman Law, (2009).

Bignardi A., "Actio, interdictum, arbores". Contributo allo studio dei rapporti di vicinato, in: Index, 12 (1983-1984).

Biondi B., Le servitù prediali nel diritto romano, (1954).

Capogrossi Colognesi L., La struttura della proprieta e la formazione dei iura praediorum nelleta repubblicana, (1976).

Caravella R., Le limitazioni del dominio per ragioni di vicinanza in diritto romano, (1971).

Fiorentini M., Struttura ed esercizio della servitù d'acqua nellesperienza giuridica romana, in: Quaderni del Dipartimento di Scienze Giuridiche, 8 (2003), pp. 51-197.

Grosso G., Le servitù prediali nel diritto romano, (1969).

Kamińska R., Procesual and Extrajudicial Protection of Easment of Passage in Roman Law, in: Alternative Dispute Resolution: From Roman Law to Contemporary Regulations, ed. 
by B. Sitek, J. J. Szczerbowski, K. Ciućkowska-Leszczewicz, C. Lázaro Guillamòn, S. P. Kursa, A. W. Bauknecht, (2016).

Lenel O., Das Edictum perpetuum, (1927).

Mantovani D., Le formule del processo privato romano. Per la didattica delle Istituzioni di diritto romano, (1999).

Piniński L., Pojęcie i granice prawa własności według prawa rzymskiego, (1900).

Pistolesi O., Le attività di ripristino nelle servitù di iter, actus e via, in: Studi in onore di Arnaldo Biscardi, ed. by F. Pastori, 5 (1984).

Rodger A., Owners and Neighbours in Roman Law, (1972).

Seyed-Mahdavi Ruiz S., Die rechtlichen Regelungen der Immissionen im römischen Recht und in ausgewählten europäischen Rechtsordnungen, (2000).

Solazzi S., La tutela e il possesso delle servitù prediali, (1949).

Solazzi S., Requisiti e modi di costituzione delle servitù prediali, (1938).

Zuccotti F., Le servitù prediali nel mondo antico. Dogmatica romanistica e prospettive storico-comparatistiche, in: Studi in onore di Remo Martini, 3 (2009).

Zuccotti F., Sulla tutela processuale delle servitù cosiddette pretorie, in: Atti del Convegno Processo civile e processo penale nellesperienza giuridica del mondo antico, (Collana della Rivista di diritto romano 2011). 